\title{
Effect of Space Holders on Fabrication of Porous Titanium Alloy-Hydroxyapatite Composite through Powder Injection Molding
}

(Kesan Pemegang Ruang terhadap Pembentukan Komposit Aloi Titanium-Hidroksiapatit Berbusa melalui Pengacuan Suntikan Serbuk)

\author{
FARrahshaida Mohd SAlleh, Abu BaKar SulonG*, MuHammad RAFi RaZa, \\ NORHAMIDI MUHAMAD \& LIM TSIU FHANG
}

\begin{abstract}
Powder injection molding (PIM) is able to produce porous titanium alloy/hydroxyapatite composite through the space holder technique. Thermal debinding and sintering processes were the main challenges due to different properties of metal and ceramic in producing such composite. This study focused on the effect of different space holders on the physical and mechanical properties of debound and sintered porous titanium aloi/hydroxyapatite composite. The feedstock is containing of $80 \mathrm{wt}$. \% of titanium alloy/hydroxyapatite with $20 \mathrm{wt}$. \% of space holders such as sodium chloride (NaCl) and polymethylmethacrylate (PMMA), respectively. The binders were then removed from the injected samples by two stages of debinding; solvent and thermal debinding. The sintering was performed at three different temperatures $1100^{\circ} \mathrm{C}, 1200^{\circ} \mathrm{C}$ and $1300^{\circ} \mathrm{C}$ at a heating rate of $10^{\circ} \mathrm{C} / \mathrm{min}$ and holding time of $5 \mathrm{~h}$. It was found that the samples containing PMMA space holder was fractured after sintering. While, the samples containing $\mathrm{NaCl}$ space holder successfully formed pores and not fractured. At sintering temperature of $1300^{\circ} \mathrm{C}$, the density, compressive strength and porosity volume percentages for the sintered sample containing $\mathrm{NaCl}$ space holder were $3.05 \mathrm{~g} / \mathrm{cm}^{3}, 91.7 \mathrm{MPa}$. and 11.9 vol\%, respectively.
\end{abstract}

Keywords: Hydroxyapatite; metal foam; powder injection molding; space holder; titanium alloy

ABSTRAK

Pengacuan suntikan serbuk (PIM) boleh menghasilkan komposit aloi titanium/hidroksiapatit berbusa dengan menggunakan teknik pemegang ruang. Proses bagi penyahikatan dan persinteran merupakan cabaran utama disebabkan sifat bahan logam dan seramik yang berbeza dalam penghasilan komposit tersebut. Fokus kajian ini adalah kesan berbeza pemegang ruang terhadap sifat fizikal dan mekanik penyahikatan serta persinteran komposit aloi titanium-hidroksiapatit berbusa. Bahan suapan mengandungi $80 \%$ bt. aloi titanium/hidroksiapatit dengan $20 \%$ bt.pemegang ruang seperti sodium klorida $(\mathrm{NaCl})$ dan polimetilmetakrilat (PMMA). Bahan pengikat kemudian disingkirkan daripada sampel yang disuntik melalui dua peringkat penyahikatan; larutan dan penyahikatan terma. Persinteran dijalankan pada tiga suhu yang berbeza $1100^{\circ} \mathrm{C}, 1200^{\circ} \mathrm{C}$ dan $1300^{\circ} \mathrm{C}$ pada kadar pemanasan sebanyak $10^{\circ} \mathrm{C} /$ min dan masa pegangan selama 5 jam. Didapati sampel yang mengandungi pemegang ruang PMMA hancur selepas persinteran. Manakala, sampel yang mengandungi pemegang ruang $\mathrm{NaCl}$ berjaya menghasilkan liang-liang berbusa dan tidak hancur. Pada suhu persinteran $1300^{\circ} \mathrm{C}$, ketumpatan, kekuatan mampatan dan peratusan isi padu keliangan sebanyak $3.05 \mathrm{~g} / \mathrm{cm}^{3}, 91.7 \mathrm{MPa}$. dan $11.9 \mathrm{vol} \%$.

Kata kunci: Aloi Titanium; hidroksiapatit; logam berbusa; pemegang ruang; pengacuan suntikan serbuk

\section{INTRODUCTION}

The use of titanium alloys, cobalt-chromium alloys, and stainless steel began in the 1960s (Best et al. 2008). Titanium and its alloys are widely used for bone implants due to their strong mechanical properties and high chemical resistance. Ti-6Al-4V has a higher Young's modulus compared to human bones, which leads to stress shielding (Nomura et al. 2010). It also has poor biocompatibility and unable to promote the growth of natural tissue (Thian et al. 2001). Hydroxyapatite (HA) is a ceramic material, which has poor mechanical properties and limited for high load applications. However, it has a chemical structure that is similar to human bone and able to stimulate tissue growth (Chu et al. 2006). The Ti-
6Al-4V and HA composites are able to form a biomaterial with good biological and mechanical properties as well as good corrosion resistance (Thian et al. 2002). Powder Metallurgy (PM) or Powder Injection Molding (PIM) has been used in the fabrication of metal composites for biomedical implants application (Deing et al. 2014; Jurczyk 2012). In biomedical implants, the concept of preparing porous structure is developed due to enhance the ingrowth of tissue into the pores. Therefore in PM, there are various techniques that are able to fabricate porous composite such as gas entrapment (Murray \& Dunand 2003), conventional pressing and sintering (Oh et al.2003) and space holder (Bram et al. 2002; Manonukul et al. 2010; Raza et al. 2014; Wen et al. 2001). 
Sodium chloride $(\mathrm{NaCl})$ and polymethylmethacrylate (PMMA) were chosen as the space holders in this experiment. $\mathrm{NaCl}$ is widely available in the market which is low cost, low toxicity, soluble in water where it can be easily eliminated through the solvent debinding process (Patnaik 2003). In addition, $\mathrm{NaCl}$ provides good adhesion and cell spread during the in vivo process of porous NiTi (Kohl et al. 2008). Torres et al. (2012) found that the important factors in controlling the dissolution rate of porosity and Young's modulus were salt content, immersion time and water temperature. The other space holder; PMMA, was chosen due to its lightweight and good impact strength. Nishiyabu et al. (2005) initially demonstrated the potential of PMMA as space holder in producing a macropores structure with PM. Indeed, it was found that PMMA is suitable as a space holder where the acceptable level of oxygen and carbon content based on the ASTM standards was obtained for porous Titanium Alloy after sintered at $600^{\circ} \mathrm{C}$ (Engin et al. 2011).

Recent research has shown that there are challenges in combining two or more powders having different properties such as size, materials and thermal coefficient. Ti-6Al-4V and HA composites have been studied for several years due to their capabilities in biomedical implantation (Arifin et. al 2015; Thian et al 2002). However, combining these two materials is complicated due to different thermal expansion coefficient that results to residual stress which will form crack on the sintered part (Pattanayak et al. 2011; Thian et. al 2002). In addition, since porous structure of Ti-6Al-4V/HA composite is needed, the cell size and its distribution had to be controlled to ensure such structure is similar to human bone. The main objective was to analyse the effects of debinding and sintering parameters on Ti-6Al-4V/HA composite containing $\mathrm{NaCl}$ and PMMA space holders using PIM. A preliminary study of a porous structure for human bone was expected in this study.

\section{MATERIALS AND METHODS}

The gas atomized Ti-6Al-4V and HA were manufactured by TLS Technik GmbH, Germany and Sigma, Aldrich, respectively. $\mathrm{NaCl}$ and PMMA were chosen as the space holders. $\mathrm{NaCl}$ proved to be a better choice as a temporary space holder because it can be removed easily through dissolution in water and non-toxic, which is suitable for bio-implant application (Jha et al.2013). Table 1 shows the size and density of the raw materials used in this study. A multi-component binder system consists of polyethylene glycol (PEG), poly-methyl methacrylate (PMMA) and stearic acid (SA) was used. PEG binder is an environmentally friendly material and can be dissolved in water easily. PMMA acted as the backbone binder due it provides enough strength for handling purpose and can be removed from the injected part in a short time (Omar \& Davies 2001). Meanwhile, stearic acid worked as a surfactant for powder wetting (Ibrahim et al. 2009).

The morphological analysis was carried out for Ti-6Al$4 \mathrm{~V}$, HA and space holders by using FESEM Machine Model Zeiss Merlin Compact. The XRD analysis was performed using a diffractometer with a radiation of over a 2-theta range at 10-90 degrees using a Bruker D8 machine. Figure 1 shows the FESEM images of powders and space holders. It was observed that the particle shape for Ti-6Al-4V, $\mathrm{HA}, \mathrm{PMMA}$ and $\mathrm{NaCl}$ is spherical, irregular, spherical and rectangular, respectively.

Differential scanning calorimetry (DSC) analysis was conducted using DSC 1 Mettler Toledo to measure the melting temperature of the binder components prior preparing the feedstock as according to ASTM D3418 (standard test method for transition temperatures and enthalpies of fusion and crystallization of polymers). The STA 449 F3 NETZSC thermal gravimetric analyser (TGA) was used to measure the decomposition temperature of the binder components so that the temperatures for mixing and debinding can be designed based on ASTM E1131 (standard test method for compositional analysis by thermogravimetric). A heating rate of $10^{\circ} \mathrm{C} / \mathrm{min}$ was used for both tests from the ambient temperature to $700^{\circ} \mathrm{C}$ in nitrogen condition.

A dry ball milling machine was used to mix 90 wt. $\%$ Ti-6Al-4V and $10 \mathrm{wt}$ \% $\mathrm{HA}$ at a speed of $100 \mathrm{rpm}$ for $2 \mathrm{~h}$, as reported by Arifin et al. (2015). 80 wt. \% Ti-6Al$4 \mathrm{~V} / \mathrm{HA}$ was then mixed with 20 wt. $\%$ of space holders using a Brabender Plastograph ${ }^{\circledR}$ EC plus machine at room temperature at a speed of $40 \mathrm{rpm}$ for $2 \mathrm{~h}$ to maintain the space holder structure where it helps to form pores during sintering. The mixture of $60 \mathrm{vol} \% \mathrm{Ti}-6 \mathrm{Al}-4 \mathrm{~V} / \mathrm{HA}-\mathrm{space}$ holder was then mixed with 40 vol. $\%$ of a PEG-based binders system consists of 70 vol.\% PEG, 25 vol.\% PMMA and 5 vol. $\%$ SA using the brabender machine at $160^{\circ} \mathrm{C}$ and at the speed of $40 \mathrm{rpm}$ for $2 \mathrm{~h}$. The prepared feedstock was molded into a tensile bar by using a table-top injection moulding machine (model DSM Xplore). The molding parameters were in accordance with previous research done by Raza et al. (2014), as shown in Table 2.

TABLE 1. Characterization of raw materials

\begin{tabular}{cccc}
\hline Raw Material & Type & $\begin{array}{c}\text { Measured } \\
\text { Particle Size }(\mu \mathrm{m})\end{array}$ & Density $\left(\mathrm{g} / \mathrm{cm}^{3}\right)$ \\
\hline Ti-6Al-4V & Gas Atomized powder & 19.61 & 4.43 \\
Hydroxyapatite (HA) & Powder & 5.341 & 3.132 \\
NaCl & Crystalline & 381.396 & 2.165 \\
PMMA & Crystalline & 160 & 1.19 \\
\hline
\end{tabular}



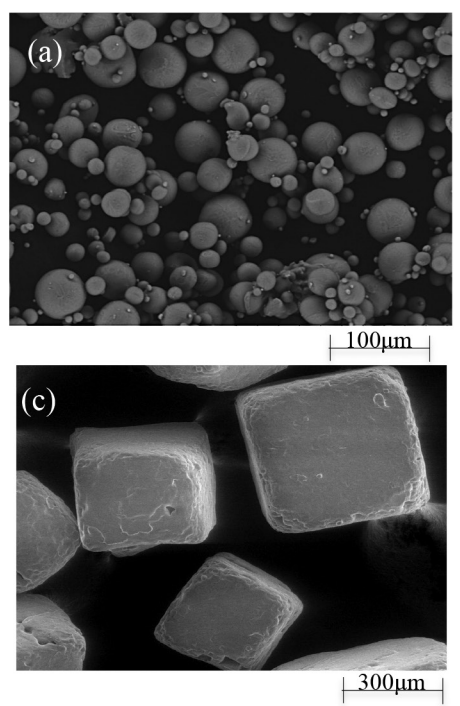

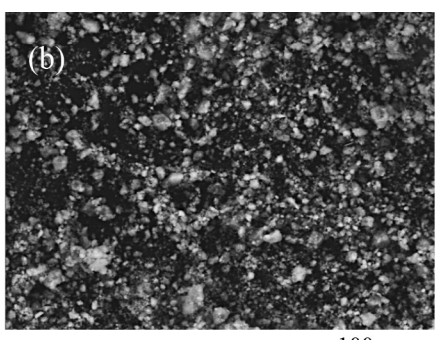

$100 \mu \mathrm{m}$

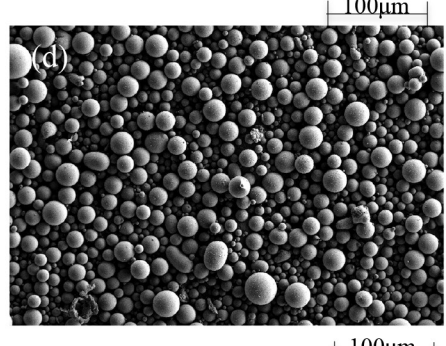

$100 \mu \mathrm{m}$

FIGURE 1. FESEM micrographs of (a) Titanium Alloy and (b) HA (c) NaCL (d) PMMA

TABLE 2. Injection molding parameters

\begin{tabular}{lc}
\hline Injection parameters & Value \\
\hline Injection pressure & $8 \mathrm{bar}$ \\
Compression pressure & $8-10 \mathrm{bar}$ \\
Holding pressure & $8-10 \mathrm{bar}$ \\
Melt temperature & $160 \pm 5^{\circ} \mathrm{C}$ \\
Mold temperature & $55 \pm 5^{\circ} \mathrm{C}$ \\
Injection time & $8 \mathrm{~s}$ \\
\hline
\end{tabular}

A two-stage debinding process starting with solvent debinding followed by thermal debinding was carried out. Solvent debinding was carried out in a distilled water bath at $60^{\circ} \mathrm{C}$ for $6 \mathrm{~h}$ to extract PEG. In thermal debinding, PMMA was removed from the solvent extracted samples by heating the samples at $500^{\circ} \mathrm{C}$ at a heating rate of $3^{\circ} \mathrm{C} / \mathrm{min}$ in an argon atmosphere with a holding time of $1 \mathrm{~h}$, using a split debinding furnace (VTC-500 4TSF). The debound samples were then subjected to sintering processing a tube furnace model HTF-15/200-60 at three different temperatures; $1100^{\circ} \mathrm{C}, 1200^{\circ} \mathrm{C}$ and $1300^{\circ} \mathrm{C}$ at a heating rate of $10^{\circ} \mathrm{C} / \mathrm{min}$ with a holding time of $5 \mathrm{~h}$. The density, compressive strength and morphologies of the sintered samples were observed. The density test was performed using the Archimedes principle according to MPIF 42 (determination of density of cocted or sintered powder metallurgy products). The compression tests were carried out on the Universal Testing Machine Model Z100 based on MPIF 61 (determination of the compressive yield strength of powder metallurgy materials).

\section{RESULTS AND DISCUSSION}

\section{X-RAY DIFFRACTION (XRD) OF POWDERS}

Based on the X-Ray diffractogram shown in Figure 2(c), it can be observed that the HA peaks show low intensity where the crystallisation of Ti-6Al-4V-6. Powder is dominant when mixing with $10 \mathrm{wt}$ \% HA. In Figure 2(e), it can be observed that peaks appeared on the Ti-6Al-4V/



FIGURE 2. XRD result (a) Ti-6Al-4V (b) HA (c) Ti-6Al-4V /HA (d) Ti-6Al-4V/HA- NaCl (e) Ti-6Al-4V/HA- PMMA 
HA-PMMA is similar pattern to Ti-6Al-4V/HA composite peaks. Meanwhile, Figure 2(d) shows that the sample consist of Ti-6Al-4V/HA-NaCl composed of three peaks; the Ti-6Al-4V, $\mathrm{HA}$ and $\mathrm{NaCl}$ peaks.

\section{MORPHOLOGY OF GREEN SAMPLE}

Figure 3 shows the morphology images of green samples containing (a) PMMA and (b) $\mathrm{NaCl}$ space holders. It was observed that the surface of green sample containing PMMA space holder looked denser and well dispersed compared to that of $\mathrm{NaCl}$ space holder. This is due to not all $\mathrm{NaCl}$ melted which resulted to poor wetting on the surface of powder particles.

\section{THREE-POINT BENDING TEST OF GREEN SAMPLE}

The comparison between PMMA and $\mathrm{NaCl}$ space holders on the flexural strength, modulus and elongation is presented in Figure 4. Samples containing PMMA space holder showed better performance compared to that of $\mathrm{NaCl}$ space holder. This is because PMMA was presented in a larger quantity and acted as the backbone binder compared to $\mathrm{NaCl}$.
Therefore, green samples containing PMMA have higher resistance towards deformation and breakage.

\section{SOLVENT DEBINDING OF GREEN SAMPLE}

Figures 5 and 6 shows the SEM micrographs for both samples containing different space holders where samples with $\mathrm{NaCl}$ space holder formed more pores compared to those with PMMA space holder. This is due to the removal of PEG and $\mathrm{NaCl}$ during the solvent debinding, which resulted to significant formation of pores. After $30 \mathrm{~min}$ of removing $\mathrm{NaCl}$, as shown by Figure 5(a), large holes were observed. Such formation significantly appeared after 150 min due to more PEG and $\mathrm{NaCl}$ components were removed, as shown in Figure 5(c). Based on Figures 6 , it was observed that initially, the sample looked dense and wet because PMMA space holder was presented in a large quantity. Manonukul et al. (2010) reported when more PMMA is added, the wettability with less viscosity of feedstock is higher. After $150 \mathrm{~min}$, the surface of sample formed micropores and seemed to be less dense. In addition, the pores formed in the samples containing
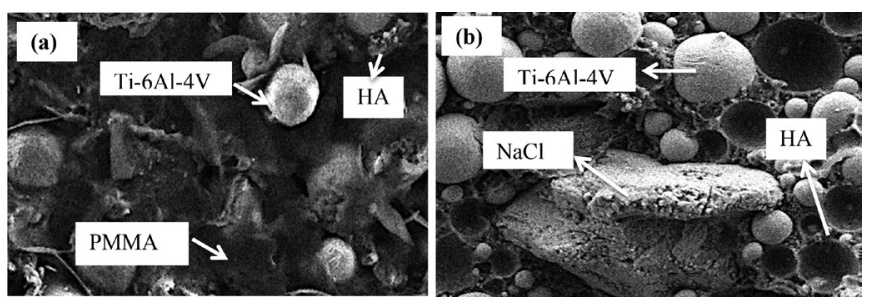

FIGURE 3. SEM micrographs for green sample consisting (a) PMMA and (b) $\mathrm{NaCl}$ space holder
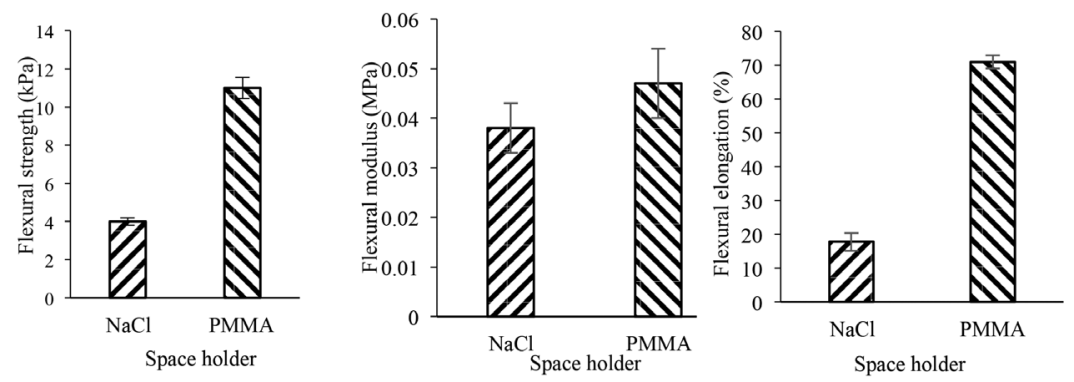

FIGURE 4. Comparison of (a) flexural strength (b) flexural modulus and (c) flexural elongation for green part contain different types of space hold
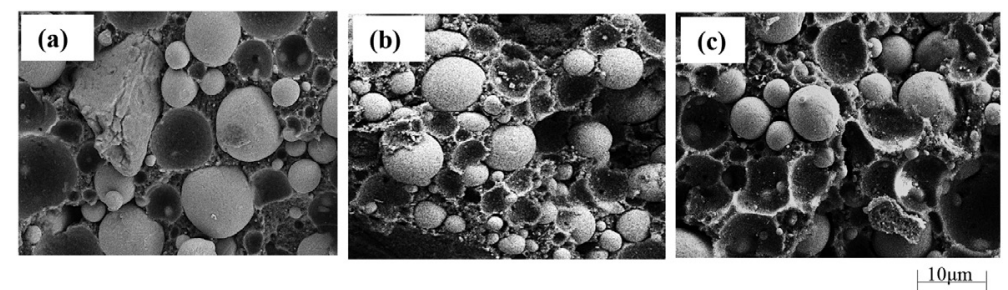

FIGURE 5. SEM micrographs for sample containing $\mathrm{NaCl}$ space holder after (a) $30 \mathrm{~min}$

(b) $150 \mathrm{~min}$ and (c) 360 min solvent extraction 

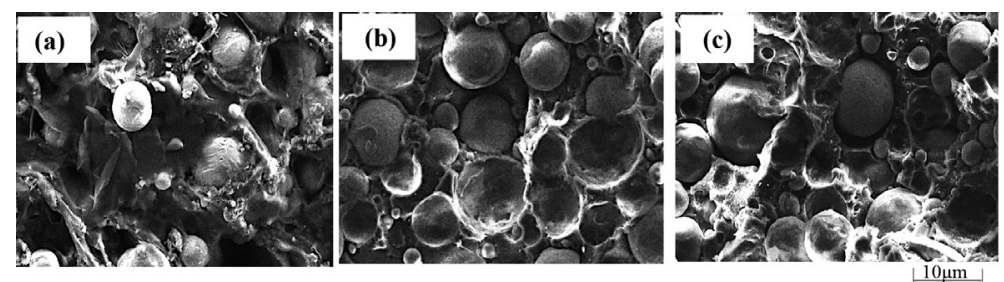

FIGURE 6. SEM micrographs for sample containing PMMA space holder after (a) 30 min (b) 150 min and (c) 360 min solvent extraction

PMMA space holder are smaller compared to those containing $\mathrm{NaCl}$ space holder.

\section{THERMAL DEBINDING AND SINTERING ANALYSIS}

Samples containing $\mathrm{NaCl}$ space holder was successfully debound, however, was observed on the debound samples containing PMMA space holder. Swelling is a known defect that commonly occurred during thermal debinding process (Enneti et al. 2012), due to improper decomposition of binders. Large amount of PMMAresulted to severe swelling. In addition, the heating rate of $3^{\circ} \mathrm{C} / \mathrm{min}$ may have been too high for the samples containing PMMA space holder. Such swelling was reported when a high heating rate was used to decompose 50\% PMMA with extra dwell time (Manonukul et al. 2010). Therefore, a lower heating rate is necessary to refrain the formation of such defect. Figure 7 shows that the sample containing PMMA space holder fractured at minimum sintering temperature of $1100^{\circ} \mathrm{C}$. Pachauri and Hamiuddin (2016) reported that the quality of debound part affects the quality of the sintered part. Such influence was proven based on the debound PMMA space holder samples that have defects. Samples containing $\mathrm{NaCl}$ space holder were successfully sintered at three different temperatures; $1100^{\circ} \mathrm{C}, 1200^{\circ} \mathrm{C}$ and $1300^{\circ} \mathrm{C}$ and remained in good condition. (a)

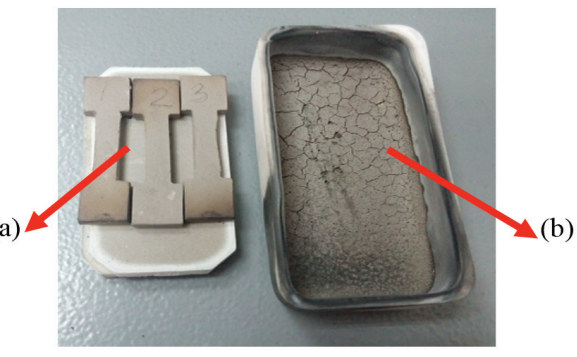

FIGURE 7. Physical deformation after sintering temperature at $1100^{\circ} \mathrm{C}$ (a)Ti-6Al-4V/HA withNaCl(b) Ti-6Al-4V/HA withPMMA

Morphology analysis was conducted on Ti-6Al-4V/HA samples containing $\mathrm{NaCl}$ space and presented in Figure 8 where the samples were sintered at different temperatures; (a) $1100^{\circ} \mathrm{C}$, (b) $1200^{\circ} \mathrm{C}$ and (c) $1300^{\circ} \mathrm{C}$. It was observed that more necking occurred at $1300^{\circ} \mathrm{C}$ and relatively larger that the sample sintered at $1100^{\circ} \mathrm{C}$. Thian et al. (2002) reported Ti-6Al-4V/HA sintered at $1100^{\circ} \mathrm{C}$ showed the pores are interconnected. In addition, sufficient necking regions between particles were formed while maintaining open pore structure. Such structure was formed due to the decomposition of the binder system (Weil et al. 2006).

Based on Table 3, the volume percentage of pores formed was inversely proportional to the increasing
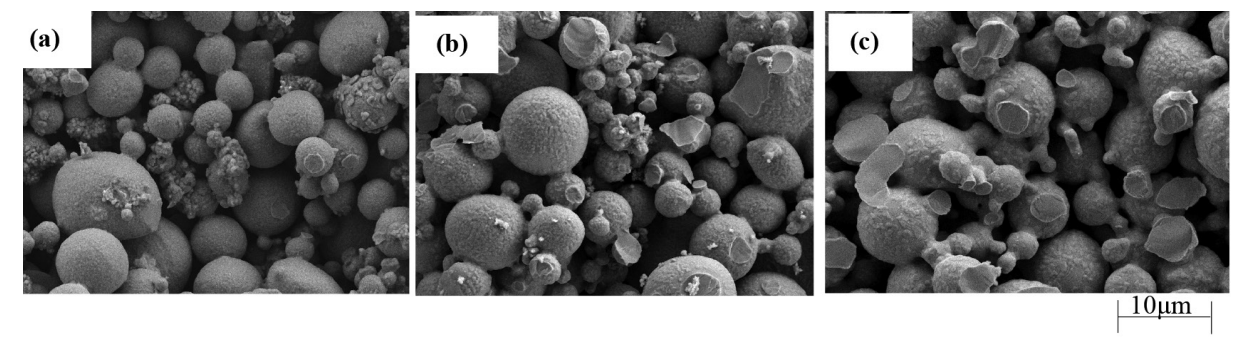

FIGURE 8. SEM images for sample sintered at (a) $1100^{\circ} \mathrm{C}$, (b) $1200^{\circ} \mathrm{C}$ and (c) $1300^{\circ} \mathrm{C}$

TABLE 3. Volume percentage of pores at three different sintering temperatures Ti-6Al-4V/HA-NaCl

\begin{tabular}{cc}
\hline $\begin{array}{c}\text { Sintering temperature } \\
\left({ }^{\circ} \mathrm{C}\right)\end{array}$ & $\begin{array}{c}\text { Porosity volume percentage } \\
(\%)\end{array}$ \\
\hline 1100 & $20.8 \pm 0.3$ \\
1200 & $18.3 \pm 0.1$ \\
1300 & $11.9 \pm 0.3$ \\
\hline
\end{tabular}




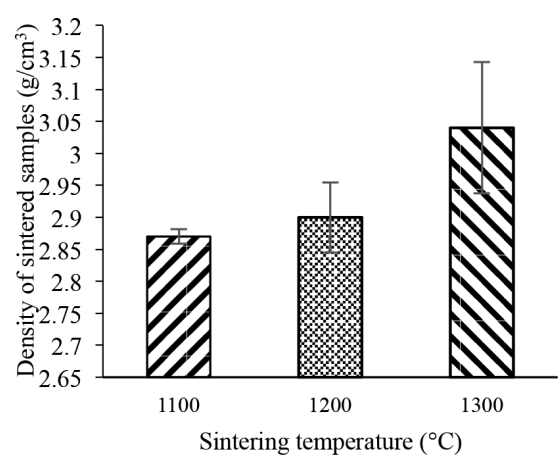

(a)

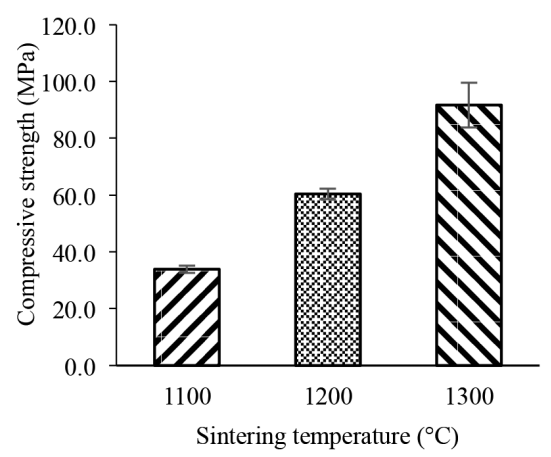

(b)

FIGURE 9. (a) Density and (b) Compressive strength of Ti-6Al-4V/HA-NaCl samples sintered at $1100^{\circ} \mathrm{C}, 1200^{\circ} \mathrm{C}$ and $1300^{\circ} \mathrm{C}$

sintering temperature, as referred to the previous research by Ahmad et al. (2010). The formation of pores was the least when the highest sintering temperature of $1300^{\circ} \mathrm{C}$ was applied. This is due to the enlargement of necking when the sintering temperature increased. Such enlargement covers the pores that formed between the particles. According to Raza et al. (2015), pores were reduced and the enlargement of necking was found to be aligned with the increasing holding time of 4 to 5 $\mathrm{h}$, when titanium alloy/HA composite was sintered at $1300^{\circ} \mathrm{C}$. Arifin $(2015)$ found that necking was clearly observed at $1300^{\circ} \mathrm{C}$ compared to $1100^{\circ} \mathrm{C}$ and $1200^{\circ} \mathrm{C}$. Figure 9(a) shows the density of sintered samples at different sintering temperatures. As expected, the highest density was given by the sample sintered at $1300^{\circ} \mathrm{C}$ due to more necking was formed and enlarged (Ji et al. 2001). Therefore, the formation of necking eventually increased the density of sample and reducing the pore size and its volume. Meanwhile, the compressive strength of the sintered samples increased as the sintering temperature increased, as shown by Figure 9(b). Such finding is similar as reported by Arawi et al. (2012). The density and strength of titanium alloy particles were directly proportional with the sintering temperature (German 1996); therefore higher compressive strength is needed to break the sample.

\section{CONCLUSION}

Poor thermal debinding process will produce sintered samples with poor mechanical properties. Such hypothesis was proven by the samples containing PMMA space holder where appropriate heating rate and holding time for binder removal are needed. However, porous Ti-6Al-4V/HA composite containing $\mathrm{NaCl}$ space holder was successfully fabricated and the porosity for such composite decreased from 20.8 to 11.9 vol\% when sintered from $1100^{\circ} \mathrm{C}$ to $1300^{\circ} \mathrm{C}$. 20.8 to 11.9 vol\% porous $\mathrm{Ti}-6 \mathrm{Al}-4 \mathrm{~V} / \mathrm{HA}-\mathrm{NaCl}$ composite with density and compressive strength of $3.05 \mathrm{~g} / \mathrm{cm}^{3}$ and $91.7 \mathrm{MPa}$ was obtained when sintered at $1300^{\circ} \mathrm{C}$.

\section{ACKNOWLEDGEMENTS}

The authors would like to thank Universiti Kebangsaan Malaysia for the financial supports (Grant TRGS/2/2014/ UKM/02/4/1 and PRGS/1/2017/TK03/UKM/02/2).

\section{REFERENCES}

Ahmad, S., Muhamad, N., Muchtar, A., Sahari, J., Jamaludin, K.R., Ibrahim, M.H.I., Mohamad Nor, N.H. \& Murtadhahadi. 2010. Characterisation of titanium foams sintered at different temperatures prepared by the slurry method. Sains Malaysiana 39(1): 77-82.

Arawi,A.Z.O., Ramli, R.\& Talari, M.K. 2012. Study of sintering temperature for nano-hydroxyapatite with addition of titanium. Advanced Materials Research 538-541: 2392-2395.

Arifin, A., Sulong, A.B., Muhamad, N., Syarif, J. \& Ramli, M.I. 2015. Powder injection molding of HA/Ti6Al4V composite using palm stearin as based binder for implant material. Material and Design 65: 1028-1034.

Arifin, A. 2015. Pengacuanan suntikan serbuk hidroksiapatit/ Ti6Al4V komposit menggunakan pengikat berasaskan stearin sawit, PhD Tesis, Universiti Kebangsaan Malaysia (Unpublished).

Best, S.M., Porter, A.E., Thian, E.S. \& Huang, J. 2008. Bioceramics: Past, present and the future. Journal of the European Ceramic Society 28: 1319-1327.

Bram, M., Ahmad-Khanlou, A., Heckmann, A., Fuchs, B., Buchkremer, H. \& Stöver, D. 2002. Powder metallurgical fabrication processes for NiTi shape memory alloy parts. Mater. Sci.Eng. A Struct. 337: 254-263.

Chu, C., Xue, X., Zhu, J. \& Yin, Z. 2006. Fabrication and characterization of titanium-matrix composite with $20 \mathrm{vol} \%$ hydroxyapatite for use as heavy load-bearing hard tissue replacement. J. Mater. Sci-Mater. Med. 17: 245-251.

Deing, A., Luthringer, B., Laipple, D., Ebel, T. \& Willumeit, R. 2014. A porous TiAl6V4 implant material for medical application. International Journal of Biomaterials 2014: Article ID. 904230.

Engin, G., Bülent, A. \& Gülsoy, H.Ö. 2011. Injection molding of micro-porous titanium alloy with space holder technique. Rare Metals 30(6): 565-571.

Enneti, R.K., Park, S.J., German, R.M. \& Atre, S.V. 2012. Review: Thermal debinding process in particulate materials processing. Materials and Manufacturing Processes 27: 103-118. 
German, R.M. 1996. Sintering Theory and Practice. 1st ed. Canada: John Wiley \& Son Inc.

Ibrahim, M.H.I., Muhamad, N. \& Sulong, A.B. 2009. Rheological investigation of water atomised stainless steel. International Journal of Mechanical and Materials Engineering 4: 1-8.

Jha, N., Mondal, D.P., Dutta Majumdar, J., Badkul, A., Jha, A.K. \& Khare,A.K. 2013. Highly porous open cell Ti-foam using $\mathrm{NaCl}$ as temporary space holder through powder metallurgy route. Materials and Design 47: 810-819.

Ji, C.H., Loh, N.H., Khor, K.A. \& Tor, S.B. 2001. Sintering study of $316 \mathrm{~L}$ stainless steel metal injection molding parts using Taguchi method: Final density. Materials Science and Engineering A 311: 74-82.

Jurcyzk, M. 2012. Bionanomaterials for Dental Applications. New York: Taylor \& Francis.

Köhl, M., Bram, M., Buchkremer, P., Stöver, D., Habijan, T. \& Köller, M. 2008. In Proceedings of the Fifth International Conference on Porous Metals and Metallic Foams, edited by Lefeb-vre, P., Banhart, J. \& Dunand, D.C. Destech Publications Inc. pp. 295-298.

Manonukul, A., Muenya, N., Leaux, F. \& Amaranan, S. 2010. Effects of replacing metal powder space holder on metal foam produced by metal injection moulding. Journal of Materials Processing Technology 210: 529-535.

Murray, N.G.D. \& Dunand, D.C. 2003. Microstructure evolution during solid-state foaming of titanium. Composite Science Technology 63: 2311-2316.

Nishiyabu, K., Matsuzaki, S., Okubo, K., Ishida, M.\& Tanaka, S. 2005 . Porous graded materials by stacked metal powder hotpress moulding. Materials Science Forum 492-493: 765-770.

Nomura, N., Sakamoto, K. \& Takahashi, K. 2010. Fabrication and mechanical properties of porous Ti/HA for bone fixation devices. Materials Transactions 51(8): 1449-1454.

Oh, I.H., Nomura, N., Masahashi, N. \& Hanada, S. 2003. Mechanical properties of porous titanium compacts prepared by powder sintering. Scripta Materialia 49: 1197-1202.

Omar, M.A. \& Davies, H.A. 2001. The influence of PMMA content on the properties of $316 \mathrm{~L}$ stainless steel MIM compact. J. of Materials Processing Technology 113: 471481.

Pachauri, P. \& Hamiuddin, M. 2016. Optimization of debinding process in metal injection molding (MIM) for high density of sintered part. Int. J. Adv. Mater Metallurgical Eng. 2(1): $12-22$.

Patnaik, P. 2003. Handbook of Inorganic Chemicals. New York: McGraw-Hill.

Pattanayak, D., Rao, B.T. \& Mohan, T.R.R. 2011. Calcium phosphate bioceramics and bioceramic composites. J. Sol-Gel Sci. Technol. 59: 432-447.

Raza, M.R., Sulong, A.B., Muhamad, N., Majid, N.A. \& Rajabi, J. 2015. Effects of binder system and processing parameters on formability of porous Ti-6Al-4V/HA composite through powder injection moulding. Material \& Design 87: 386-392.
Raza, M.R., Sulong, A.B., Muhamad, N., Majid, N.A., Rajabi, J. \& Amir, A. 2014. Optimization of binder and process parameters to produce Ti/HA foam through micro powder injection molding. Advanced Material Conference (AMC) 32: 307-312.

Thian, E.S., Loh, N.H., Khor, K.A. \& Tor, S.B. 2002.Ti-6Al-4V/ HA composite feedstock for injection molding. Materials Letters 56: 522-532.

Thian, E.S., Loh, N.H., Khor, K.A. \& Tor, S.B. 2001. Effects of debinding parameters on powder injection molded Ti6Al-4V/HA composite parts. Advances Powder Technology 12(3): 361-370.

Torres, Y., Pavon, J.J. \& Rodriguez, J.A. 2012. Processing and characteristic of porous titanium for implants by using $\mathrm{NaCl}$ as space holder. Journal of Material Processing 212: 1061-1069.

Weil, K.S., Nyberg, E. \& Simmons, K. 2006. A new binder for powder injection molding and other reactive metals. Journal of Material Processing Technology 176: 205-209.

Wen, C.E., Mabuchi, M., Yamada, Y., Shimojima, K., Chino, Y. \& Asahina, T. 2001. Processing of biocompatible of Ti and Mg. Scr. Mater. 45(10): 1147-1153.

Farrahshaida Mohd Salleh, Abu Bakar Sulong*,

Norhamidi Muhamad \& Lim Tsiu Fhang

Department of Mechanical and Materials Engineering

Faculty of Engineering and Built Environment

Universiti Kebangsaan Malaysia

43600 Bangi, Selangor Darul Ehsan

Malaysia

Farrahshaida Mohd Salleh

Faculty of Mechanical Engineering

Universiti Teknologi MARA

40450 UiTM Shah Alam, Selangor Darul Ehsan

Malaysia

Muhammad Rafi Raza

Department of Mechanical Engineering

COMSATS Institute of Information Technology, Sahiwal

Pakistan

*Corresponding author; email: abubakar@ukm.edu.my

Received: 28 April 2016

Accepted: 31 May 2017 